Przegląd Badań Edukacyjnych Educational Studies Review

ISSN 1895-4308

nr $26(1 / 2018)$, s. $21-44$

ORYGINALNE ARTYKULY BADAWCZE

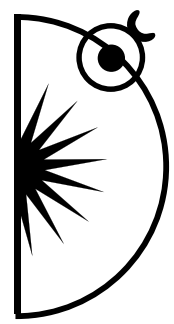

Magdalena Szubielska ORCID: 0000-0002-8437-0871

Katolicki Uniwersytet Lubelski Jana Pawła II, Instytut Psychologii, e-mail: magdasz@kul.pl

\title{
Wpływ zajęć edukacyjnych prowadzonych w przestrzeni galerii na odbiór abstrakcyjnej sztuki współczesnej przez uczniów młodszych klas szkoły podstawowej
}

http://dx.doi.org/10.12775/PBE.2018.002

\section{The Influence of Educational Workshops Held in a Gallery on the Reception of Abstract Contemporary Art by Primary Education Students}

\begin{abstract}
The article presents experimental research on the influence of a guided tour at an exhibition of contemporary abstract art on the aesthetic perception of the exhibition by primary school students. The study was conducted in a natural context of viewing art in a gallery where original works by a contemporary artist were presented during a temporary exhibition. The independent variables in the study were: guided tour around the exhibition by a gallery employee (yes, no) and the age of the students (younger: $\mathrm{M}=7.77$ years old, older: $\mathrm{M}=8.95$ years old). For older students, an increased aesthetical preference after an informal educational workshop (guided tour) was discovered. Furthermore, a developing trend was established, that for older students in relation to younger students, a decrease in positive emotions caused by viewing art and a decrease in overall liking of the exhibition were observed. It was particularly apparent under control conditions when the students did not participate in the guided tour. The results obtained partially confirm the results of previous studies on art reception by a young audience, and partially contradict them. In the discussion section, the discrepancies are explained emphasizing the superiority of research conducted in exhibition spaces where
\end{abstract}


a higher ecological accuracy of the obtained results is provided in comparison to research on aesthetic perception in laboratory conditions.

Key words: informal education, contemporary abstract art, early school children, psychological aspects of art reception, experimental research.

\section{Wprowadzenie teoretyczne}

Sławomir Pasikowski (2014) uznaje wiedzę o zależnościach przyczynowo-skutkowych za nie do przecenienia w zakresie poznawania mechanizmów edukacji, a także skuteczności procedur praktyki edukacyjnej. Badania eksperymentalne mają tę przewagę nad badaniami korelacyjnymi, że pozwalają ustalić nie tylko zależność między dwiema zmiennymi, ale i kierunek tej zależności (Brzeziński, 1996; Francuz, Mackiewicz, 2005). tzn. którą ze zmiennych możemy traktować jako przyczynę badanego zjawiska. Innymi słowy - wyniki eksperymentu dają wiedzę o tym, czy (i w jakim stopniu - co określa tzw. wielkość efektu) pewna zmienna, określana jako zmienna niezależna główna, wpływa na analizowane zjawisko czy proces, czyli tzw. zmienną zależną.

Jednocześnie autor ten, na podstawie analizy artykułów publikowanych w wiodących polskich czasopismach dotyczących nauczania, dostrzega deficyt badań eksperymentalnych w ramach opublikowanych studiów edukacyjnych. Chcąc określić, czy nieformalne zajęcia edukacyjne prowadzone w przestrzeni galerii wpływają na odbiór abstrakcyjnej sztuki współczesnej przez uczniów młodszych klas szkoły podstawowej, zaprojektowano eksperyment, w którym manipulowano udziałem uczniów w oprowadzaniu po wystawie.

Sztuka współczesna często postrzegana jest przez osoby, które nie mają specjalistycznego przygotowania do jej odbioru, jako bezwartościowa, dziwaczna lub niezrozumiała (Leder i in., 2004; Miecznicka, 2015; Tröndle, Kirchberg, Tschacher, 2014). Laików w dziedzinie sztuki interesuje przede wszystkim to, co przedstawia dzieło, a nie jego unikatowy styl czy walory kompozycyjne. Innymi słowy - laicy koncentrują się na treści wytworu artystycznego, nie przywiązują zaś wagi do jego analizy formalnej (Bhattacharya, Petsche, 2002; Cupchik, Gebotys, 1988; Waligórska, 2006). W badaniach stwierdzono, że laicy uznają za bardziej zrozumiałe dzieła figuratywne niż abstrakcyjne, a także częściej je preferują (Cupchik i in., 1994; Furnham, Walker, 2001a; 2001b; Geger, Leder, 2015; Millis, 2001; Swami, 2013; Szubielska, Niestorowicz, Bałaj, 2016). Większość współcześnie tworzonych dzieł to prace nieprzedstawiające lub nierealistyczne, co sprawia, że odbiorcom, którzy nie mają wykształ- 
cenia w dziedzinie sztuki, duży kłopot sprawia ich rozumienie, a co za tym idzie - nie są zainteresowani ich kontemplacją (por. Silvia, 2005). Trudności w akceptacji sztuki współczesnej przez laików, spowodowane jej hermetycznym językiem, dostrzegają sami artyści wizualni, czyniąc z tego zagadnienia temat realizowanych prac - w tym Karolina Breguła, w ramach projektów: 66 rozmów o wspótczesnej sztuce, 2007; Nie rozumiem, 2009; Biuro thumaczeń sztuki, 2010; Ttumaczenie sztuki, 2011. Intuicyjne działania artystki, związane z przeświadczeniem o tym, że laikom odwiedzającym galerie należy dostarczyć informacji kontekstowych o dziele, aby zaczęli oni rozumieć i doceniać sztukę, znajdują potwierdzenie w badaniach empirycznych (Belke i in., 2010; Gerger, Leder, 2015; Millis, 2001; Russell, 2003; Russell, Milne, 1997; Swami, 2013). $\mathrm{W}$ badaniach tych stwierdzono, że zapoznanie się z informacjami kontekstowymi, takimi jak opis prac czy ich tytuł, wpływa na wzrost poczucia zrozumienia dzieł przez nieprofesjonalnych odbiorców, a także wzrost pozytywnych emocji wywołanych obcowaniem ze sztuką. Duclos, Philippeaux i Poli (2010), na podstawie wywiadów przeprowadzonych z dziećmi odwiedzającymi muzeum historyczne, z jednej strony stwierdzili, że spontanicznie korzystały one z informacji kontekstowej zawierającej opisy eksponatów dedykowane dziecięcemu odbiorcy i zwykle oceniały je jako ciekawe. $Z$ drugiej strony - dzieci te prosiły o wsparcie rodziców, domagały się wyjaśnienia niejasnych zagadnień i rozwinięcia zawartych w opisach informacji, które ich zainteresowały. Autorzy nie analizowali jednak wpływu opisów prac na ocenę oglądanych dzieł (nie prowadzili systematycznej analizy odbioru estetycznego eksponatów ani nie ujęli w planie badawczym grupy kontrolnej dzieci, którym nie zaprezentowano opisów prac).

Uczniów młodszych klas szkoły podstawowej możemy uznać za nieprofesjonalnych odbiorców sztuk wizualnych - dzieci te w programie edukacji formalnej nie mają przedmiotów związanych $\mathrm{z}$ historią sztuki. Ponadto $\mathrm{w}$ ramach wyjść zorganizowanych sporadycznie odwiedzają muzea i galerie (mimo że kształcenie w nieformalnym kontekście oglądania wystawy, jako interesujące i efektywne, może stanowić ciekawą alternatywą dla lekcji prowadzonych w szkole - por. Brajčić, Kovačević, Kuščević, 2013). Z badań wynika, że sztuka nowoczesna i współczesna nie jest preferowana przez dziecięcych odbiorców, którzy wolą od niej: prace pozbawione wartości artystycznej, wytwory plastyczne dzieci, a także realistyczne dzieła figuratywne z wcześniejszych okresów historii sztuki (Kuscevic, Kardum, Brajcic, 2014; Nissel, Hawley-Dolan, Winner, 2016). Mając świadomość tego, że obecnie tworzona sztuka może sprawiać trudność dziecięcemu odbiorcy, wiele instytucji wystawienniczych 
prowadzi różnego rodzaju zajęcia edukacyjne opracowane specjalnie z myślą o najmłodszych widzach, których celem jest zainteresowanie dzieci sztuką współczesną (zob. np. Szary, Sztorc, Ryczkowska, 2015). W badaniach wpływu oprowadzania kuratorskiego po wystawie na odbiór estetyczny figuratywnej sztuki współczesnej stwierdzono, że taka forma edukacji w przestrzeni galerii powoduje wzrost preferencji estetycznej współczesnej sztuki figuratywnej co ujawnia się zwłaszcza u dzieci w wieku przedszkolnym, które dodatkowo w sytuacji, gdy nie biorą udziału w oprowadzaniu, oceniają sztukę XX i XXI wieku gorzej niż dzieci wczesnoszkolne (Szubielska i in., 2017; Wójtowicz, Szubielska, Szymańska, 2017). Młodsze dzieci mogą bardziej potrzebować wskazówek ułatwiających rozumienie dzieł niż dzieci starsze, ponieważ wraz z wiekiem uczniów zwiększa się umiejętność interpretacji dzieł sztuki (Smith, Smith, 2008). O większych trudnościach w interpretacji sztuki XX wieku przez młodszych niż starszych uczniów może świadczyć też wynik badania Kuscevic i zespołu (2014), w którym stwierdzono, że uczniowie starsi przypisywali obrazom z tego okresu wyższą wartość niż uczniowie młodsi.

W niniejszym badaniu postanowiono sprawdzić: Czy udział w zajęciach edukacyjnych w formie oprowadzania po wystawie abstrakcyjnej sztuki współczesnej powoduje wzrost preferencji estetycznej i pozytywnych emocji estetycznych, a także ułatwia interpretację abstrakcyjnych dzieł oglądanych w galerii sztuki przez uczniów będących na początkowym etapie edukacji szkolnej? Ponadto eksploracji poddano zagadnienia: Czy w odbiorze estetycznym uczniów wczesnych klas szkoły podstawowej zachodzą różnice rozwojowe (tj. czy odbiór estetyczny zmienia się wraz z wiekiem uczniów)? Czy udział w oprowadzaniu zmienia sposób interpretacji oglądanych prac? Dotychczasowa literatura przedmiotu nie pozwala na postawienie w tym miejscu hipotez badawczych, ponieważ jak dotąd nie prowadzono badań odbioru abstrakcyjnych dzieł przez uczniów w naturalnym kontekście oglądania ich w przestrzeni galerii. W populacji dzieci badano dotąd jedynie bądź to odbiór abstrakcyjnej sztuki w warunkach laboratoryjnych (Nissel i in., 2016), bądź to percepcję estetyczną figuratywnej sztuki współczesnej w przestrzeni wystawienniczej (Szubielska i in., w trakcie recenzji; Wójtowicz i in., 2017). Z wcześniejszych eksperymentów wynika zaś, że dzieła abstrakcyjne oceniane są przez laików inaczej niż figuratywne (Cupchik i in., 1994; Furnham, Walker, 2001a; 2001b; Geger, Leder, 2015; Millis, 2001; Swami, 2013; Szubielska i in., 2016), a także - że kontekst oglądania prac (laboratorium vs. naturalna przestrzeń wystawiennicza) zmienia ich odbiór estetyczny (Brieber, Nadal, Leder, 2014; Brieber i in., 2014). 


\section{Metoda}

\section{Osoby badane}

W badaniach wzięło udział 95 uczniów początkowych klas szkoły podstawowej, w tym 48 dziewczynek i 47 chłopców. Wiek uczniów wahał się od 6,5 do 11 lat (średnia wieku $M=8,34$ lat, odchylenie standardowe $S D=0,76$ ). Badani przychodzili do galerii sztuki współczesnej w ramach zorganizowanych przez szkołę wyjść. Ankietowano wyłącznie tych uczniów, których rodzice wyrazili pisemną zgodę na udział w eksperymencie ${ }^{1}$.

$\mathrm{Na}$ etapie analizy danych badanych podzielono na 2 grupy wiekowe: uczniów młodszych (w wieku od 6,5 do 8 lat, $M=7,77, S D=0,41$ ) i starszych (w wieku od 8 lat 1 miesiąca do 11 lat, $M=8,95, S D=0,55$ ).

\section{Materialy}

Przedmiotem oceny była wystawa pt. „Jeśli nie tutaj, gdzie?” współczesnej artystki wizualnej Alicji Bielawskiej, która odbyła się w dniach 17.02.2017 - 09.09.2017 r. w Galerii Labirynt w Lublinie. Na wystawie prezentowano 15 abstrakcyjnych prac: rysunków, rzeźb i instalacji (sama artystka często określa je mianem „przedmiotów”). Na planie wystawy (zob. Aneks 1) poszczególne prace miały następujące numery: (1) Konstelacja poranna (II), 2016; (2) Wektor (I, II), 2016; (3) Mufka na trapezie, 2014; (4) Punkty odniesienia (wersja odwrócona), 2016; (5) Wywinięte na druga stronę, 2017; (6A, 6B, 6C) z serii Różnica zawarta jest w skali, 2016; (7A, 7B) Rzeczy z serii Miejsca, 2014; (8) Patrze na stońce $i$ widze hula-hoop, 2017; (9) Z nonszalancja odwracając na druga strone, 2017; (10A, 10B) z serii Przemienny porzadek, 2017; (11) Z widokiem prostopadlym do horyzontu, 2017 (zob. Aneks 2).

Do oceny odbioru estetycznego wystawy służyła ankieta, zawierająca pytania o emocje wywołane oglądaniem wystawy, preferencje estetyczne oraz interpretację prac (zob. Aneks 1). Emocje mierzono z wykorzystaniem podskali znak emocji metody SAM (The Self Assessment Manikin) Bradleya i Langa (1994). Pozostałe pytania ankiety stanowiły opracowanie własne.

\section{Procedura}

Badania odbywały w przestrzeni Galerii Labirynt w Lublinie. Miały one charakter grupowy. Grupy uczniów losowo przydzielano do jednego z dwu warunków badawczych: kontrolnego $(N=40$, wiek: $M=8,27, S D=0,65)$ bądź eks-

${ }^{1}$ Eksperyment realizowany był w ramach badań statutowych pt. Percepcja sztuki współczesnej w przestrzeni galerii przez dzieci. 
perymentalnego ( $N=55$, wiek: $M=8,39, S D=0,83)$. Badanie rozpoczynało się od przywitania się pracownika galerii z uczniami i zapoznania ich z zasadami panującymi w galerii (z których najważniejszą była zasada niedotykania prac). W warunku kontrolnym uczniowie dokonywali oceny wystawy bez zapoznania się ze wskazówkami interpretacyjnymi, które przekazywał edukator. W warunku eksperymentalnym ocena estetyczna następowała po oprowadzaniu po wystawie. Oprowadzanie miało charakter interaktywny. Podczas oprowadzania przewodnik opowiadał o eksponowanych pracach, do których kolejno podchodzono, oraz aktywizował grupę pytaniami o skojarzenia związane z oglądanymi dziełami sztuki. Oprowadzanie trwało około 30 minut. Po obejrzeniu wystawy (samodzielnym lub któremu towarzyszyło oprowadzanie) uczniowie pozostawali w przestrzeni wystawienniczej i wypełniali ankietę odbioru estetycznego. Kolejne pytania ankiety czytano dzieciom na głos. W razie trudności zespół prowadzący badania pomagał uczniom zaznaczać wybrane przez nich odpowiedzi (dotyczyło to zwłaszcza zadania zaznaczania prac na planie wystawy) ${ }^{2}$.

Jako operacjonalizację zmiennej zależnej emocja estetyczna przyjęto pięciostopniową, dwubiegunową, rysunkową podskalę znak emocji metody SAM (Bradley, Lang, 1994). Preferencję mierzono na pięciostopniowej, dwubiegunowej skali rysunkowej, na której zaznaczano podobanie się wystawy jako całości. Ponadto na planie wystawy należało zaznaczyć preferowaną pracę artystki. Preferencję badano też, zadając pytania o to, czy badani mieliby ochotę dotknąć prac prezentowanych na wystawie (traktując chęć eksploracji jako wskaźnik związanego z preferencją zainteresowania), a także czy chcieliby ponownie odwiedzić galerię, w celu obejrzenia podobnej wystawy. Pomiarowi sposobu i umiejętności interpretacji służyły: polecenie wyboru najdziwniejszego dzieła znajdującego się na wystawie oraz pytanie otwarte o to, co chciała widzom przekazać artystka, przygotowując niniejszą wystawę.

\section{Wyniki}

Odpowiedzi zaznaczone na dwubiegunowych rysunkowych skalach emocji i preferencji kodowano, przyporządkowując im po odwróceniu skali wartości liczbowe od 1 do 5 (wyższe wartości liczbowa na skalach oznaczały bardziej pozytywną emocję oraz wyższą preferencję). Wszystkie analizy danych przeprowadzono z wykorzystaniem pakietu statystycznego SPSS.

2 Serdecznie dziękuję Paniom Agnieszce Kasprzak, Emilii Lipie i Agacie Sztorc za pomoc w organizacji i przeprowadzeniu badań. 


\section{Emocje wywołane oglądaniem wystawy}

Po wykonaniu analizy wariancji dla zmiennej zależnej znak emocji i czynników międzyobiektowych udział w zajęciach edukacyjnych w galerii (tak, nie) oraz wiek uczniów (młodsi, starsi) stwierdzono istotny statystycznie efekt główny czynnika wiek, $F(1,91)=4,03, p=0,048, \eta^{2}=0,04$. Wystawa wywoływała bardziej pozytywne emocje u młodszych $(M=4,43, S D=0,58)$ niż u starszych uczniów $(M=4,13, S D=0,91)$. Efekt główny czynnika udział w zajęciach edukacyjnych, $F(1,91)=0,49, p=0,484$, a także interakcja analizowanych czynników, $F(1,91)=0,49, p=0,484$, nie były istotne statystycznie.

\section{Preferencje estetyczne}

Podobanie się uczniom wystawy. Wykonano analizę wariancji dla zmiennej zależnej podobanie się wystawy i czynników międzyobiektowych udział w zajęciach edukacyjnych w galerii (tak, nie) oraz wiek uczniów (młodsi, starsi). Stwierdzono efekt główny czynnika wiek, $F(1,91)=8,11, p=0,005, \eta^{2}=0,08$. Wystawa bardziej podobała się młodszym $(M=4,51, S D=0,54)$ niż starszym $(M=4,22, S D=0,60)$ dziecięcym odbiorcom. Efekt główny czynnika udział

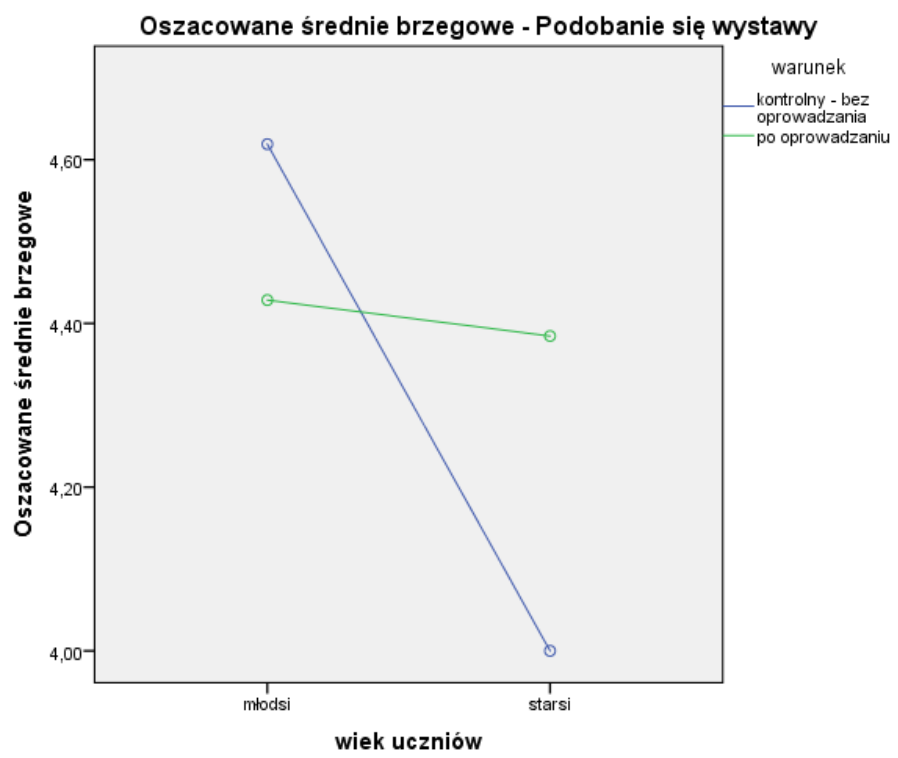

Rycina 1. Interakcyjny wpływ udziału w oprowadzaniu po wystawie oraz wieku uczniów na podobanie się wystawy.

Źródło: dane z badań własnych. 
w oprowadzaniu po wystawie okazał się nieistotny statystycznie, $F(1,91)=$ $=0,70, p=0,407$, ale czynnik ten wchodził $\mathrm{w}$ istotną interakcję $\mathrm{z}$ czynnikiem wiek uczniów, $F(1,91)=6,10, p=0,015, \eta^{2}=0,06$ (zob. Rycina 1 ). Po policzeniu testów $\mathrm{t}$ dla grup niezależnych w podgrupach wyodrębnionych ze względu na poziomy analizowanych czynników stwierdzono, że interakcja ta polegała na tym, że oprowadzanie po wystawie wpływało pozytywnie na jej podobanie się jedynie $\mathrm{w}$ grupie uczniów starszych, $t(43)=-2,21, p=0,032$. Ponadto stwierdzono, że tylko w warunkach kontrolnych, tj. gdy dzieci oglądały wystawę bez przewodnictwa edukatora, $t(38)=3,64, p=0,001$, wystawa istotnie bardziej podobała się uczniom młodszym niż starszym.

Chęć dotknięcia prac. Rozkład odpowiedzi na pytanie: „Czy miałeś/miałaś ochotę dotknąć prac prezentowanych na wystawie?" zawiera tabela 1. Po obliczeniu testów chi kwadrat niezależności z poprawką Yatesa (którą zastosowano ze względu na liczebności oczekiwane mniejsze niż 5) stwierdzono brak istotnego statystycznie wpływu udziału w oprowadzaniu po wystawie na chęć dotknięcia prac. Brak wpływu stwierdzono, analizując odpowiedzi uczniów młodszych, $\chi^{2}(1)=0,90, p=0,344$, starszych, $\chi^{2}(1)=1,50, p=0,221$, a także wszystkich badanych dzieci, $\chi^{2}(1)=3,79, p=0,052$.

Chęć odwiedzenia podobnej wystawy w przyszłości. Rozkład odpowiedzi na pytanie: „Czy chciałbyś/chciałabyś ponownie odwiedzić galerię i obejrzeć podobną wystawę?" zawiera tabela 2 . Obliczono testy chi kwadrat niezależności z poprawką Yatesa (ze względu na stwierdzone liczebności oczekiwane mniejsze niż 5), stwierdzając brak istotnego statystycznie wpływu udziału w oprowadzaniu po wystawie na chęć zobaczenia podobnej wystawy w przyszłości. Brak wpływu stwierdzono analizując odpowiedzi uczniów starszych, $\chi^{2}(1)=0, p=1,00$, a także odpowiedzi wszystkich uczniów, którzy wzięli udział $\mathrm{w}$ badaniu, $\chi^{2}(1)=0, p=1,00$. W grupie uczniów młodszych policzenie testów chi kwadrat nie było możliwe ze względu na to, że wszyscy młodsi badani deklarowali chęć odwiedzenia podobnej wystawy w przyszłości (dla tej zmiennej zależnej już na poziomie statystyk opisowych nie stwierdzono żadnej zmienności odpowiedzi ze względu na udział w oprowadzaniu). 
Tabela 1. Rozkład częstości w zakresie chęci dotknięcia prac prezentowanych na wystawie, uwzględniający podział na grupy wiekowe i udział w oprowadzaniu po wystawie

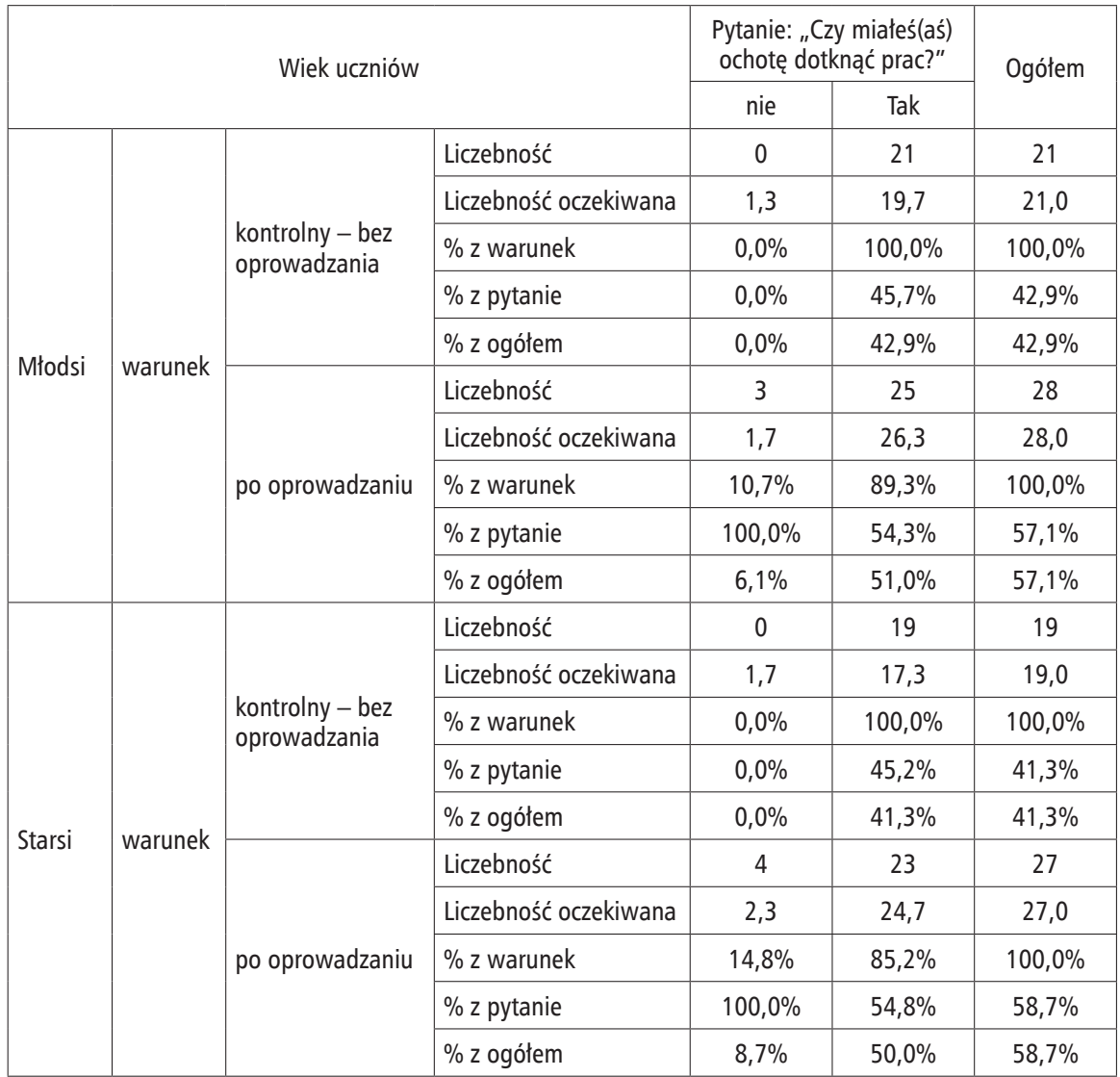

Źródło: dane z badań własnych. 
Tabela 2. Rozkład częstości w zakresie chęci ponownego odwiedzenia galerii i obejrzenia podobnej wystawy, uwzględniający podział na grupy wiekowe i udział w oprowadzaniu po wystawie

\begin{tabular}{|c|c|c|c|c|c|c|}
\hline & & Wiek uczniów & & $\begin{array}{r}\text { Pytanie: „ } \\
\text { byś) pono } \\
\text { galerię i o } \\
\text { ną u }\end{array}$ & $\begin{array}{l}\text { hciałbyś(a- } \\
\text { odwiedzić } \\
\text { zeć podob- } \\
\text { wę?" }\end{array}$ & Ogółem \\
\hline & & & & nie & Tak & \\
\hline & & & Liczebność & 0 & 21 & 21 \\
\hline & & & Liczebność oczekiwana & 0 & 21,0 & 21,0 \\
\hline & & kontrolny - bez & $\%$ z warunek & $0 \%$ & $100,0 \%$ & $100,0 \%$ \\
\hline & & & $\%$ z pytanie & $0 \%$ & $42,9 \%$ & $42,9 \%$ \\
\hline Mtodsi & unungk & & \% z ogółem & 0 & $42,9 \%$ & $42,9 \%$ \\
\hline & & & Liczebność & 0 & 28 & 28 \\
\hline & & & Liczebność oczekiwana & 0 & 28,0 & 28,0 \\
\hline & & po oprowadzaniu & $\%$ z warunek & $0 \%$ & $100,0 \%$ & $100,0 \%$ \\
\hline & & & $\%$ z pytanie & $0 \%$ & $57,1 \%$ & $57,1 \%$ \\
\hline & & & \% z ogółem & $0 \%$ & $57,1 \%$ & $57,1 \%$ \\
\hline & & & Liczebność & 1 & 18 & 19 \\
\hline & & & Liczebność oczekiwana & 1,3 & 17,7 & 19,0 \\
\hline & & kontrolny - bez & $\%$ z warunek & $5,3 \%$ & $94,7 \%$ & $100,0 \%$ \\
\hline & & & $\%$ z pytanie & $33,3 \%$ & $42,9 \%$ & $42,2 \%$ \\
\hline Storei t & (1) & & \% z ogółem & $2,2 \%$ & $40,0 \%$ & $42,2 \%$ \\
\hline Stalst & . warlumen & & Liczebność & 2 & 24 & 26 \\
\hline & & & Liczebność oczekiwana & 1,7 & 24,3 & 26,0 \\
\hline & & po oprowadzaniu & $\%$ z warunek & $7,7 \%$ & $92,3 \%$ & $100,0 \%$ \\
\hline & & & $\%$ z pytanie & $66,7 \%$ & $57,1 \%$ & $57,8 \%$ \\
\hline & & & \% z ogółem & $4,4 \%$ & $53,3 \%$ & $57,8 \%$ \\
\hline
\end{tabular}

Źródło: dane z badań własnych.

Wybór preferowanej pracy. Częstość wyboru poszczególnych prac jako tych, które najbardziej podobały się odbiorcom, ze względu na ich udział w oprowadzaniu po wystawie, zawiera tabela 3 . W tabeli tej zamieszczono też wyniki testów chi kwadrat niezależności, za pomocą których testowano wpływ oprowadzania po wystawie na wybór poszczególnych prac jako preferowanych. Wszystkie policzone testy okazały się nieistotne statystycznie. 
Tabela 3. Częstość wyboru poszczególnych prac jako preferowanych w grupach wyodrębnionych ze względu na udział w oprowadzaniu po wystawie oraz wyniki testu chi kwadrat niezależności (Pearsona bądź testu z poprawką Yatesa - w zależności od uzyskanych liczebności oczekiwanych; "-" oznacza, że w danym wypadku obliczenie testu chi kwadrat nie było możliwe)

\begin{tabular}{|c|c|c|c|c|c|}
\hline \multirow{3}{*}{$\begin{array}{c}\text { Numer pracy, } \\
\text { według opisu } \\
\text { na planie } \\
\text { wystawy }\end{array}$} & \multicolumn{4}{|c|}{ Warunek } & \multirow{3}{*}{$\begin{array}{l}\text { Wynik testu } \\
\text { chi kwadrat } \\
\text { niezależności }\end{array}$} \\
\hline & \multicolumn{2}{|c|}{ bez oprowadzania } & \multicolumn{2}{|c|}{ po oprowadzaniu } & \\
\hline & liczebność & $\%$ z warunek & liczebność & $\%$ z warunek & \\
\hline 1 & 0 & $0 \%$ & 0 & $0 \%$ & - \\
\hline 2 & 2 & $5 \%$ & 1 & $1,9 \%$ & $x^{2}(1)=0,05, p=0,817$ \\
\hline 3 & 9 & $22,5 \%$ & 15 & $28,8 \%$ & $x^{2}(1)=0,47, p=0,492$ \\
\hline 4 & 8 & $20 \%$ & 15 & $28,8 \%$ & $x^{2}(1)=0,94, p=0,331$ \\
\hline 5 & 3 & $7,5 \%$ & 5 & $9,6 \%$ & $x^{2}(1)=0, p=1,00$ \\
\hline $6 \mathrm{~A}$ & 0 & $0 \%$ & 0 & $0 \%$ & - \\
\hline $6 B$ & 0 & $0 \%$ & 0 & $0 \%$ & - \\
\hline $6 C$ & 0 & $0 \%$ & 0 & $0 \%$ & - \\
\hline $7 \mathrm{~A}$ & 0 & $0 \%$ & 0 & $0 \%$ & - \\
\hline $7 B$ & 0 & $0 \%$ & 0 & $0 \%$ & - \\
\hline 8 & 13 & $32,5 \%$ & 12 & $23,1 \%$ & $x^{2}(1)=1,01, p=0,314$ \\
\hline 9 & 1 & $2,5 \%$ & 0 & $0 \%$ & $x^{2}(1)=0,02, p=0,895$ \\
\hline $10 \mathrm{~A}$ & 3 & $7,5 \%$ & 4 & $7,7 \%$ & $x^{2}(1)=0, p=1,00$ \\
\hline $10 \mathrm{~B}$ & 0 & $0 \%$ & 0 & $0 \%$ & - \\
\hline 11 & 1 & $2,5 \%$ & 0 & $0 \%$ & $x^{2}(1)=0,02, p=0,895$ \\
\hline
\end{tabular}

Źródło: dane z badań własnych

\section{Interpretacja dziel}

Interpretacja intencji artystki. Za pomocą testu chi kwadrat niezależności porównywano częstość braku podania interpretacji w postaci opisu intencji artystki (tj. odpowiedzi: „Nie wiem”, „Nie mam zielonego pojęcia”, brak wpisania jakiejkolwiek interpretacji słownej; Jeden uczeń z grupy eksperymentalnej odpowiadając na pytanie o intencje artystki, zapisał ciąg znaków geometrycznych) w grupie, która brała udział w oprowadzaniu po wystawie, oraz w grupie kontrolnej. Test chi kwadrat Pearsona okazał się istotny statystycznie, $\chi^{2}(1)=$ $=4,32, p=0,038$. Brak podania interpretacji był częstszy wśród uczniów, którzy brali udział w oprowadzaniu po wystawie $(N=15$, co oznaczało $27,3 \%$ odpowiedzi w tej grupie) niż wśród uczniów z grupy kontrolnej ( $N=4$, co oznaczało 
10\% odpowiedzi w tej grupie). Po obliczeniu testów chi kwadrat niezależności w wyodrębnionych grupach wiekowych stwierdzono, że za otrzymane w całej grupie badanych różnice odpowiadają wyniki uzyskane $\mathrm{w}$ grupie młodszych uczniów, chi kwadrat Yatesa: $\chi^{2}(1)=4,94, p=0,026$ (brak podania interpretacji stwierdzono tu u jednego dziecka w warunku kontrolnym, co stanowiło 4,8\% grupy, i 10 dzieci w warunku eksperymentalnym, co stanowiło $35,7 \%$ grupy). Z kolei w grupie uczniów starszych częstości braku podania interpretacji w grupie kontrolnej ( $N=3$, co stanowiło $15,8 \%$ grupy) i eksperymentalnej ( $N=5$, co stanowiło $18,5 \%$ grupy) nie różniły się istotnie, chi kwadrat Yatesa: $\chi^{2}(1)=0$, $p=1,00$. Interpretacje słowne uczniów z grup kontrolnej i eksperymentalnej zamieszczono w Aneksie 3.

Tabela 4. Częstość wyboru poszczególnych prac jako najdziwniejszych w grupach wyodrębnionych ze względu na udział w oprowadzaniu po wystawie oraz wyniki testu chi kwadrat niezależności

\begin{tabular}{|c|c|c|c|c|c|}
\hline \multirow{3}{*}{$\begin{array}{l}\text { Numer pracy, } \\
\text { według opisu } \\
\text { na planie } \\
\text { wystawy }\end{array}$} & \multicolumn{4}{|c|}{ Warunek - wybór preferowanej pracy: } & \multirow{3}{*}{$\begin{array}{c}\text { Wynik testu } \\
\text { chi kwadrat } \\
\text { niezależności* }\end{array}$} \\
\hline & \multicolumn{2}{|c|}{ bez oprowadzania } & \multicolumn{2}{|c|}{ po oprowadzaniu } & \\
\hline & liczebność & $\%$ z warunek & liczebność & $\%$ z warunek & \\
\hline 1 & 5 & $12,5 \%$ & 3 & $5,9 \%$ & $x^{2}(1)=0,54, p=0,463$ \\
\hline 2 & 0 & $0 \%$ & 3 & $5,9 \%$ & $x^{2}(1)=0,94, p=0,333$ \\
\hline 3 & 5 & $12,5 \%$ & 8 & $15,7 \%$ & $x^{2}(1)=0,17, p=0,666$ \\
\hline 4 & 1 & $2,5 \%$ & 4 & $7,8 \%$ & $x^{2}(1)=0,42, p=0,518$ \\
\hline 5 & 13 & $32,5 \%$ & 18 & $35,3 \%$ & $x^{2}(1)=0,08 p=0,780$ \\
\hline $6 \mathrm{~A}$ & 0 & $0 \%$ & 0 & $0 \%$ & - \\
\hline $6 \mathrm{~B}$ & 0 & $0 \%$ & 0 & $0 \%$ & - \\
\hline $6 C$ & 0 & $0 \%$ & 0 & $0 \%$ & - \\
\hline $7 \mathrm{~A}$ & 0 & $0 \%$ & 0 & $0 \%$ & - \\
\hline $7 \mathrm{~B}$ & 0 & $0 \%$ & 0 & $0 \%$ & - \\
\hline 8 & 4 & $10 \%$ & 1 & $2 \%$ & $x^{2}(1)=1,46, p=0,227$ \\
\hline 9 & 0 & $0 \%$ & 5 & $9,8 \%$ & $x^{2}(1)=2,48, p=0,116$ \\
\hline $10 \mathrm{~A}$ & 10 & $25 \%$ & 9 & $17,6 \%$ & $x^{2}(1)=0,73, p=0,392$ \\
\hline $10 B$ & 1 & $2,5 \%$ & 0 & $0 \%$ & $x^{2}(1)=0,02, p=0,903$ \\
\hline 11 & 1 & $2,5 \%$ & 0 & $0 \%$ & $x^{2}(1)=0,02, p=0,903$ \\
\hline
\end{tabular}

* Pearsona bądź testu z poprawką Yatesa - w zależności od uzyskanych liczebności oczekiwanych; „-" oznacza, że w danym wypadku obliczenie testu chi kwadrat nie było możliwe.

Źródło: dane z badań własnych 
Wybór najdziwniejszej pracy. Częstość wyboru poszczególnych prac jako tych, które odbiorcy uznali za najdziwniejsze, ze względu na udział uczniów w oprowadzaniu po wystawie, zawiera tabela 4. Zamieszczono w niej również wyniki testów chi kwadrat niezależności, za pomocą których testowano wpływ oprowadzania po wystawie na wybór poszczególnych prac jako preferowanych. Wszystkie policzone testy okazały się nieistotne statystycznie.

\section{Dyskusja wyników}

Głównym celem eksperymentu było ustalenie, czy udział w zajęciach edukacyjnych prowadzonych $\mathrm{w}$ galerii sztuki współczesnej powoduje u uczniów początkowych klas szkoły podstawowej wzrost preferencji estetycznej i pozytywnych emocji wywołanych oglądaniem sztuki, a także ułatwia interpretację abstrakcyjnych dzieł oglądanych w naturalnym kontekście przestrzeni wystawienniczej. Stwierdzono, że udział w oprowadzaniu po wystawie pozytywnie wpływa tylko na jeden ze wskaźników preferencji - podobanie się wystawy, w dodatku wyłącznie u starszych uczniów, nie wpływa zaś istotnie na emocje odczuwane podczas kontaktu ze sztuką, a także (co jest niezgodne z intuicją) utrudnia interpretację dzieł.

Należy podkreślić, że wartościowanie estetyczne wystawy abstrakcyjnej sztuki przez uczniów można określić jako bardzo wysokie. Niemal wszystkie dzieci, które uczestniczyły w oprowadzaniu po wystawie, a także wszystkie dzieci, które oglądały wystawę bez przewodnika, zgłaszały chęć dotknięcia eksponowanych prac - świadczy to o zainteresowaniu uczniów współczesną sztuką abstrakcyjną, chęci jej eksploracji i dogłębniejszego poznania. Interpretację tę umacnia wysoka częstość deklaracji dotyczącej chęci odwiedzenia podobnej wystawy w przyszłości - zgłaszali ją wszyscy młodsi (w wieku od 6,5 do 8 lat) oraz niemal wszyscy starsi (powyżej 8 lat - 11 lat) badani uczniowie. Oprowadzanie po wystawie nie miało wpływu na wzrost chęci dotykania prac ani wzrost chęci uczestniczenia w kolejnej, podobnej wystawie - ale w przypadku obydwu warunków eksperymentalnych pozytywne odpowiedzi na pytania o pragnienie dotykania dzieł i oglądania podobnej sztuki w przyszłości padały bardzo często. Wysoką preferencję estetyczną sztuki abstrakcyjnej stwierdzono także, mierząc stopień podobania się uczniom wystawy. Można tu mówić o uzyskaniu efektów sufitowych, zwłaszcza w grupie uczniów młodszych. Uczniom młodszym wystawa podobała się tak bardzo - nawet gdy oglądali ją bez przewodnika, że udział w oprowadzaniu nie miał istotnego wpływu na wzrost jej wartościowania. Z kolei w grupie uczniów starszych stwierdzono pozytywny wpływ oprowadza- 
nia na podobanie się dzieciom wystawy. Otrzymany wynik jest zgodny z rezultatami eksperymentów z udziałem dorosłych laików w dziedzinie sztuki, gdzie zapoznanie się z opisem dzieł, ułatwiając rozumienie prac artystów, zwiększało ich wartościowanie (Russell, 2003; Swami, 2013). Co ciekawe, we wcześniejszych badaniach nad wpływem oprowadzania po wystawie na ocenę dzieł sztuki przez dzieci (Szubielska i in., w trakcie recenzji) stwierdzono pozytywny wpływ oprowadzania u dzieci młodszych - przedszkolnych, natomiast w grupie dzieci wczesnoszkolnych wpływ ten nie okazał się istotny statystycznie. Można postawić hipotezę, iż dzieci w różnym wieku inaczej odbierają współczesną sztukę abstrakcyjną i figuratywną. Aby ją zweryfikować, w kolejnych badaniach nad percepcją estetyczną sztuki współczesnej przez młodych widzów warto byłoby zarówno kontrolować wiek odbiorców, jak i manipulować zmienną abstrakcyjności - figuratywności wytworów artystycznych.

Otrzymane efekty sufitowe w zakresie preferencji estetycznej współczesnej sztuki abstrakcyjnej przez dzieci są niezgodne z wcześniejszymi badaniami (Kuscevic i in., 2014; Nissel i in., 2016), w których stwierdzano, że dzieci nie rozumieją i nie są w stanie docenić trudnej sztuki nienaśladującej rzeczywistości, posiadającej odrębny język wyrazu i specyficzny styl (czyli sztuki, którą artyści uprawiają, począwszy od okresu awangardy aż do czasów obecnych). Rozbieżność między wynikami badań własnych i wcześniejszych badań może wyjaśnić fakt, iż w badaniu własnym percepcja i ocena estetyczna odbywały się w naturalnym kontekście odbioru sztuki i że dzieci oglądały oryginalne dzieła artystki, a Kuscevic z zespołem (2014) oraz Nissel i współpracownicy (2016) prowadzili badania poza przestrzenią wystawienniczą, eksponując badanym reprodukcje obrazów. Tschacher i współpracownicy (2012) podkreślają, że badania odbioru sztuki prowadzone poza muzeum czy galerią mają niską trafność ekologiczną i ograniczony zakres uogólniania, ponieważ kontemplacja oryginalnych dzieł $\mathrm{i}$ ich reprodukcji to dwa zupełnie różne doświadczenia. Wizyta w muzeum czy galerii, za sprawą swoistej „aury” miejsca, wywołuje poczucie unikatowego klimatu obcowania ze sztuką, uczestniczenia z czymś wyjątkowym, jedynym w swoim rodzaju. Badania osób dorosłych pokazują, że w warunkach odbioru dzieł sztuki w muzeum wytwory artystów są dla widzów bardziej interesujące, pozytywnie pobudzające, a także ładniejsze, niż gdy odbiór sztuki następuje w warunkach laboratoryjnych (Brieber, Nadal, Leder, 2014; Brieber i in., 2014). Prawdopodobnie wizyta w galerii była dla badanych uczniów dużym pozytywnym przeżyciem, co przełożyło się na pozytywną postawę wobec prac, które Alicja Bielawska umieściła na wystawie, i wysokie oceny, jakie dzieci przypisały abstrakcyjnej, trudnej do zrozumienia przez laików sztuce współczesnej. 
Udział w zajęciach edukacyjnych w formie oprowadzania po wystawie nie wpływał na znak odczuwanych przez uczniów emocji, wywołanych odbiorem sztuki. Warto dodać, że ich emocje można uznać za bardzo pozytywne i że u młodszych dzieci emocje te były bardziej pozytywne niż u dzieci starszych. Podobne rezultaty otrzymano we wcześniejszych badaniach z udziałem dzieci przedszkolnych i wczesnoszkolnych, których przedmiotem był odbiór sztuki figuratywnej w przestrzeni galerii (Wójtowicz i in., 2017).

Oprowadzanie po wystawie, zamiast ułatwiać jej interpretację (co byłoby zgodne ze zdrowym rozsądkiem), utrudniało ją. Za otrzymany efekt częstszego braku interpretacji u dzieci, które brały udział w oprowadzaniu, w stosunku do dzieci, które oglądały wystawę bez przewodnika, odpowiadają wyniki uzyskane w grupie młodszych uczniów. W tym miejscu warto przypomnieć, że oprowadzanie miało charakter interaktywny - uczniowie zachęcani byli przez edukatora do dzielenia się własnymi skojarzeniami związanymi z kolejno oglądanymi pracami, co czynili bardzo ochoczo. Niemal wszyscy uczniowie, którzy znaleźli się w grupie eksperymentalnej, chętnie opowiadali o swoich asocjacjach, a w ramach postępowania zajęć dzieci zaczęły nawet w pewien sposób konkurować między sobą, prześcigając się w snuciu coraz bardziej oryginalnych skojarzeń i interpretacji. Wydaje się prawdopodobne, że młodszym uczniom, po tym, jak podali już skojarzenia do kolejno oglądanych prac, trudno było podać interpretację wystawy jako całości, wymagało to bowiem od nich przeprowadzenia procesu abstrahowania. Z kolei uczniowie z grupy kontrolnej, którzy nie byli pytani o interpretację kolejnych dzieł, interpretując wystawę, mogli po prostu podać pierwsze skojarzenie, które przychodziło im na myśl co jest zadaniem o wiele łatwiejszym niż abstrahowanie interpretacji całości $\mathrm{z}$ interpretacji cząstkowych. Treści interpretacji podawanych w grupie eksperymentalnej i kontrolnej były podobne - w obydwu warunkach padały m.in. komentarze dotyczące struktury dzieł (zwłaszcza ich koloru, ale także np. użytych materiałów), a także ich treści.

Odpowiedź na pytanie badawcze: Czy w odbiorze estetycznym uczniów wczesnych klas szkoły podstawowej zachodzą różnice rozwojowe?, okazała się pozytywna. Jak już napisano wcześniej, wystawa wywoływała bardziej pozytywne emocje u młodszych niż u starszych uczniów. Podobny efekt stwierdzono w zakresie preferencji estetycznej współczesnej sztuki abstrakcyjnej - bardziej podobała się ona młodszym niż starszym dzieciom wczesnoszkolnym, co było wyraźne zwłaszcza w sytuacji nieuczestniczenia w oprowadzaniu po wystawie. Świadczyłoby to o mniej krytycznym odbiorze sztuki współczesnej przez młodszych niż starszych uczniów. Kuscevic z zespołem (2014) uzyskali przeciwne 
wyniki - w ich badaniu starsi uczniowie przypisywali nierealistycznym figuratywnym obrazom namalowanym w XX wieku wyższą wartość niż uczniowie młodsi. Za różnice w otrzymanych wynikach mogą odpowiadać zarówno odmienny kontekst prowadzenia eksperymentów (naturalna sytuacja odbioru w galerii vs. przestrzeń pozagaleryjna), rodzaj eksponowanych uczniom dzieł (abstrakcyjne vs. figuratywne; rysunki, rzeźby i instalacje vs. obrazy), jak i wiek uczniów (6,5-11 vs. 6 - 10 lat). Pytanie o to, który z wymienionych czynników odpowiada za rozbieżności w rezultatach otrzymanych w badaniach, wymaga empirycznego rozstrzygnięcia w ramach kolejnych eksperymentów. Otrzymany $\mathrm{w}$ badaniu własnym wynik dotyczący zmian rozwojowych w preferencji estetycznej wydaje się niezgodny z konkluzją Smitha i Smith (2008), którzy twierdzą, że umiejętność interpretacji sztuki wzrasta wraz z wiekiem dzieci. Ale jest on niezgodny tylko pod warunkiem przyjęcia założenia, że rozumienie sztuki przez dzieci przekłada się na zainteresowanie nią i preferencję estetyczną, jak to zostało stwierdzone w badaniach dorosłych laików (Leder i in., 2004; Silvia, 2005). Prawdopodobne jest, że odbiorem estetycznym sztuk wizualnych przez dzieci emocje kierują $\mathrm{w}$ większym stopniu niż w przypadku osób dorosłych i że dziecko nie musi rozumieć dzieła, by docenić jego wartość (możliwe, że taka sytuacja występuje jedynie wtedy, gdy obcowanie ze sztuką odbywa się w przestrzeni wystawienniczej, co jest dla uczniów niecodziennym, wysoce emocjonującym doświadczeniem).

Udział w oprowadzaniu nie zmieniał istotnie sposobu interpretacji oglądanych prac. Częstotliwość wyboru poszczególnych dzieł jako najdziwniejszych (a także jako tych, które najbardziej podobały się odbiorcom) była niezależna od tego, czy wyboru dokonywano po obejrzeniu wystawy pod przewodnictwem edukatora, czy też bez oprowadzania po wystawie. Bez względu na warunek eksperymentalny za najdziwniejszą uczniowie uznali instalację Wywinięte na druga stronę. Praca ta składa się $\mathrm{z}$ metalowej konstrukcji o nieregularnym kształcie, zarzuconej na nią, jakby niedbale, tkaniny przypominającej kraciasty koc oraz elementów ceramicznych, zawieszonych na poziomych prętach i umieszczonych u podstawy metalowej ramy. Dzieci, które oglądały wystawę z przewodnikiem, mówiły m.in., że praca ta kojarzy im się z konstrukcjami na placach zabaw, z domkiem-namiotem z koca, a także - że ceramiczne wiszące elementy przypominają im dyndające na sznurku języki. Możliwe, że ze względu na skojarzenie $\mathrm{z}$ umieszczonymi w kontekście placu zabaw wiszącymi językami praca ta była tak często uznawana za najdziwniejszą na całej wystawie. Co ciekawe, praca ta była też przez niektóre dzieci wybierana jako preferowana. Wśród prac, które najbardziej podobały się dzieciom, znalazły 
się: Mufka na trapezie, która podczas oprowadzania często budziła skojarzenia z cyrkiem, a także wieloznaczne prace o największym na wystawie formacie i metaforycznych tytułach: Punkty odniesienia (wersja odwrócona) oraz Patrze na stońce $i$ widzę hula-hoop. Nikt nie wskazał zaś jako preferowanych dzieł rysunków. Świadczy to o otwartości młodych odbiorców na niekonwencjonalne, przestrzenne formy sztuki.

Podsumowując, uczniowie młodszych klas szkoły podstawowej okazali się odbiorcami otwartymi na odbiór, zainteresowanymi, pozytywnie nastawionymi i potrafiącymi docenić abstrakcyjną sztukę współczesną (za co prawdopodobnie odpowiadał fakt, że oglądali ją w naturalnym kontekście przestrzeni wystawienniczej). Zatem wydaje się, że warto organizować w ramach szkolnych wyjść zorganizowanych wyprawy do galerii sztuki współczesnej, co będzie przekładać się nie tylko na wzrost kompetencji kulturowych dzieci. Wyjścia takie stanowią ponadto szansę oswojenia się uczniów z językiem współczesnych sztuk wizualnych, który w miarę kolejnych doświadczeń galeryjnych ma szansę stać się dla młodego człowieka coraz bardziej transparentny. Wyjście do galerii stanowi też okazję do skorzystania z lekcji prowadzonej przez specjalistów z działu edukacji, która powinna okazać się atrakcyjną i efektywną formą zdobywania wiedzy nie tylko dla uczniów, ale i pedagogów nauczania początkowego, którzy czasem nie czują się wystarczająco kompetentni w dziedzinie nauczania o sztuce (por. Twigg, Garvis, 2010).

\section{Bibliografia}

Belke, B., Leder, H., Strobach, T., Carbon, C. C. (2010). Cognitive fluency: High-level processing dynamics in art appreciation. Psychology of Aesthetics Creativity and the Arts, 4(4), 214-222.

Bhattacharya, J., Petsche, H. (2002). Shadows of artistry: Cortical synchrony during perception and imagery of visual art. Cognitive Brain Research, 13(2), 179-186.

Brajčić, M., Kovačević, S., Kuščević, D. (2013). Learning at the museum. Croatian Journal of Education, 15(2), 159-178.

Brieber, D., Nadal, M., Leder, H. (2014). In the white cube: Museum context enhances the valuation and memory of art. Acta Psychologica, 154, 36-42, DOI: 10.1016/j.actpsy.2014.11.004.

Brieber, D., Nadal, M., Leder, H., Rosenberg, R. (2014). Art in time and space: Context modulates the relation between art experience and viewing time. PLOS ONE, 9, e99019. DOI: 10.1371/journal.pone.0099019. 
Brzeziński J. (2002). Metodologia badań psychologicznych. Warszawa: Wydawnictwo Naukowe PWN.

Cupchik, G. C., Gebotys, R. J. (1988). The search for meaning in art: Interpretative styles and judgements of quality. Visual Art Research, 14(2), 38-50.

Cupchik, G. C., Shereck, L., Spiegel, S. (1994). The effects of textual information on artistic communication. Visual Arts Research, 20(1), 62-78.

Duclos, A., Philippeaux, F., Poli, M.-S. (2010). De l'utilité du «texte enfant» au musée. La Lettre de l'OCIM, 132, 28-33.

Francuz, P., Mackiewicz, R. (2005). Liczby nie wiedzą skąd pochodzą. Przewodnik po metodologii i statystyce nie tylko dla psychologów. Lublin: Wydawnictwo KUL.

Furnham, A., Walker, J. (2001a). Personality and judgement of abstract, pop art, and representational paintings. European Journal of Personality, 15(1), 57-72, DOI: 10.1002/ per.340.

Furnham, A., Walker, J. (2001b). The influence of personality traits, previous experience of art, and demographic variables on artistic preference. Personality and Individual Differences, 31(6), 997-1017, DOI: 10.1016/S0191-8869(00)00202-6.

Gerger, G., Leder, H. (2015). Titles change the aesthetic appreciations of paintings. Frontiers in Human Neuroscience, 9:464. DOI:10.3389/fnhum.2015.00464.

Kuscevic, D., Kardum, G., Brajcic, M. (2014). Visual preferences of young school children for paintings from the 20th century. Creativity Research Journal, 26(3), 297-304.

Leder, H., Belke, B., Oeberst, A., Augustin, D. (2004). A model of aesthetic appreciation and aesthetic judgments. British Journal of Psychology, 95(4), 489-508, DOI: 10.1348/0007126042369811.

Miecznicka, M. (red.) (2015). Sztuka w naszym wieku. Warszawa: Fundacja Sztuki Polskiej ING.

Millis, K. (2001). Making meaning brings pleasure: The influence of titles on aesthetic experiences. Emotion, 1(3), 320-329.

Nissel, J., Hawley-Dolan, A., Winner, E. (2016). Can young children distinguish abstract expressionist art from superficially similar works by preschoolers and animals? Journal of Cognition and Development, 17(1), 18-29, DOI: 10.1080/15248372.2015.1014488.

Pasikowski, S. (2014). Kultura metodologiczna i raportowanie badań empirycznych publikowanych w wiodących czasopismach poświęconych zagadnieniom edukacji. Kultura i Edukacja, 2(102), 103-133.

Russell, P. A. (2003). Effort after meaning and the hedonic value of paintings. British Journal of Psychology, 94(1), 99-110, DOI: 10.1348/000712603762842138. 
Russell, P. A., Milne, S. (1997). Meaningfulness and the hedonic value of paintings: Effects of titles. Empirical Studies of the Arts, 15(1), 61-73, DOI: 10.2190/EHT3-HWVM$-52 \mathrm{CB}-8 \mathrm{QHJ}$.

Silvia, P. J. (2005). Cognitive Appraisals and Interest in Visual Art: Exploring an Appraisal Theory of Aesthetic Emotions. Empirical Studies of the Arts, 23(2), 119-133, DOI: 10.2190/12AV-AH2P-MCEH-289E.

Smith, J. K., Smith, L. F. (2008). The structure of artistic and aesthetic abilities in school children. Empirical Studies of the Arts, 26(1), 117-130, DOI: 10.2190/EM.26.1.h.

Swami, V. (2013). Context matters: Investigating the impact of contextual information on aesthetic appreciation of paintings by Max Ernst and Pablo Picasso. Psychology of Aesthetics, Creativity, and the Arts, 7(3), 285-295, DOI: 10.1037/a0030965.

Szary, A., Sztorc, A., Ryczkowska, M. (2015). Labirynt bez granic. Działania edukacyjne Galerii Labirynt. Lublin: Galeria Labirynt.

Szubielska, M., Niestorowicz, E., Bałaj, B. (2016). Wpływ figuratywności obrazu i informacji katalogowej na percepcję estetyczną malarstwa współczesnego przez ekspertów i laików. Annales Universitatis Paedagogicae Cracoviensis. Studia Psychologia, 1(9), 21-34.

Szubielska, M., Wójtowicz, M., Szymańska, A., Ratomska, M., Sztorc, A. (2017/artykuł przygotowany do recenzji). Wpływ zajęć edukacyjnych towarzyszących wystawie na odbiór sztuki współczesnej przez dzieci przedszkolne i wczesnoszkolne.

Tschacher, W., Kirchberg, V., van den Berg, K., Greenwood, S., Wintzerith, S., Tröndle, M. (2012). Physiological correlates of aesthetic perception of artworks in a museum. Psychology of Aesthctics, Crcativity, and the Arts, 6(1), 96-103.

Tröndle, M., Kirchberg, V., Tschacher, W. (2014). Is this art? An experimental study on visitors' judgement of contemporary art. Cultural Sociology, 8(3), 310-332, DOI: $10.1177 / 1749975513507243$.

Twigg, D., Garvis, S. (2010). Exploring art in early childhood education. The International Journal of the Arts in Society, 5(2), 193-204.

Waligórska, A. (2006). The eye and narration: Relations of artistic expertise and mode of interpretation of narrative and non-narrative paintings. Psychology of Language and Communication, 10 (1), 45-64.

Wójtowicz, M., Szubielska, M., Szymańska, A. (2017). Aesthetic preference and emotion in children's reception of contemporary art. Poster zaprezentowany na VII Konferencji Bliżej Emocji, Lublin, 18-19.05.2017. 
Aneks 1. Ankieta odbioru estetycznego wystawy „Jeśli nie tutaj, gdzie?”

Płeć: dziewczynka // chłopiec

Wiek:

Zaznacz swoje emocje wywołane oglądaniem wystawy. Te ludziki pokazują, jak bardzo byłeś(aś) zadowolony(a), radosny(a), wesoły(a) bądź niezadowolony(a), smutny(a) oglądając wystawę.
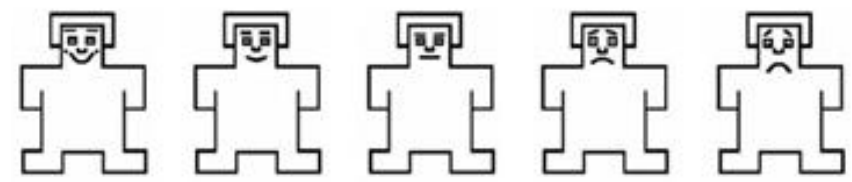

Zaznacz, w jakim stopniu podobała Ci się oglądana wystawa.
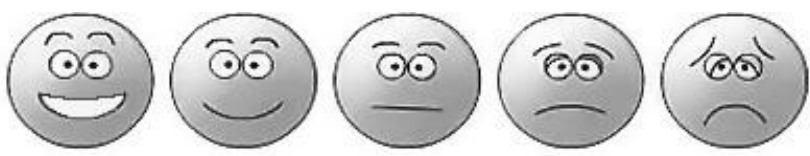

Która praca najbardziej Ci się podobała? Zaznacz na mapce kółkiem. Która praca była dla Ciebie najdziwniejsza? Zaznacz na mapce prostokątem.

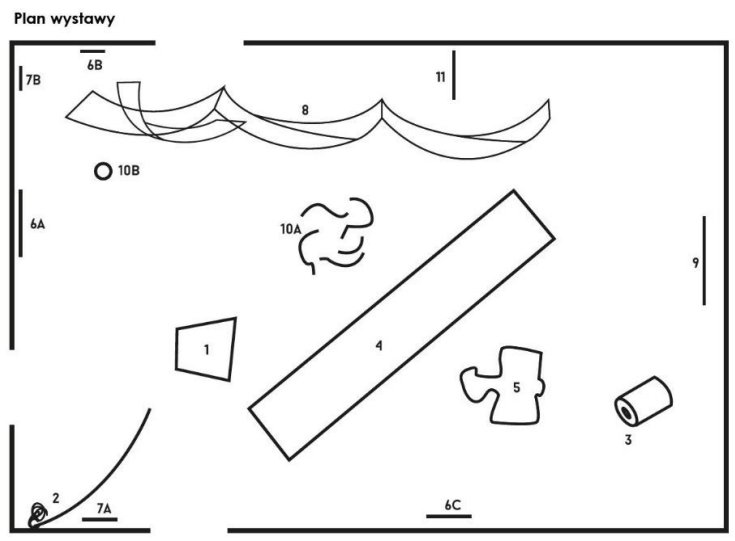

Czy miałeś/miałaś ochotę dotknąć prac prezentowanych na wystawie? tak//nie Czy chciałbyś/chciałabyś ponownie odwiedzić galerię i obejrzeć podobną wystawę? tak//nie

Jak myślisz, o czym chciała Ci opowiedzieć artystka, przygotowując tę wystawę? 
Magdalena Szubielska Wpływ zajęć edukacyjnych prowadzonych w przestrzeni galerii

Aneks 2. Reprodukcje przykładowych prac prezentowanych na wystawie (fot. Wojciech Pacewicz, dzięki uprzejmości Galerii Labirynt w Lublinie). Więcej zdjęć dokumentujących wystawę znajduje się na stronie internetowej: https://labirynt.com/alicja-bielawska/.

Mufka na trapezie

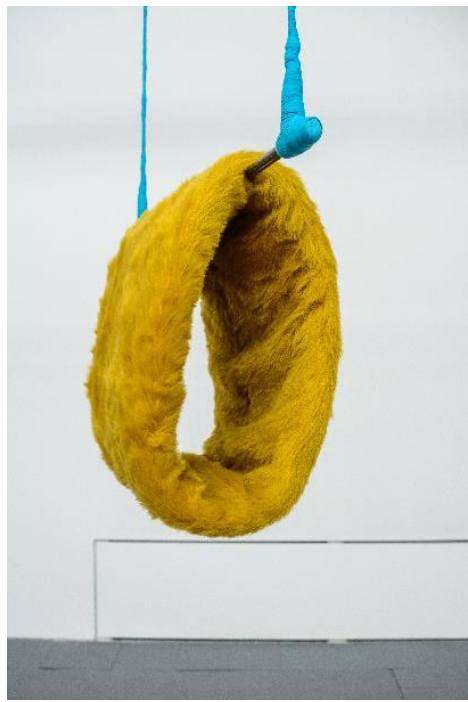

Konstelacja poranna (II)

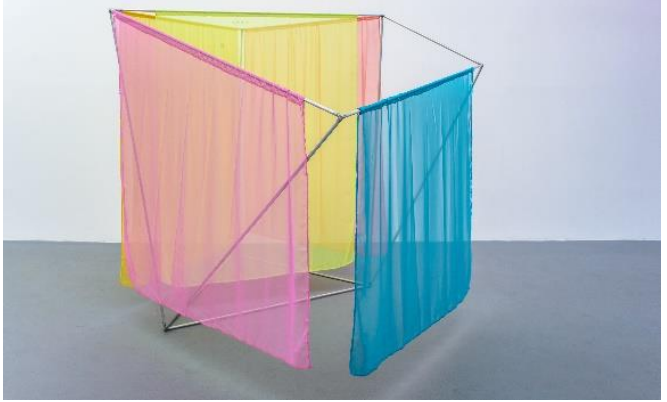


ORYGINALNE ARTYKUŁY BADAWCZE

Patrzę na stońce $i$ widzę hula-hoop

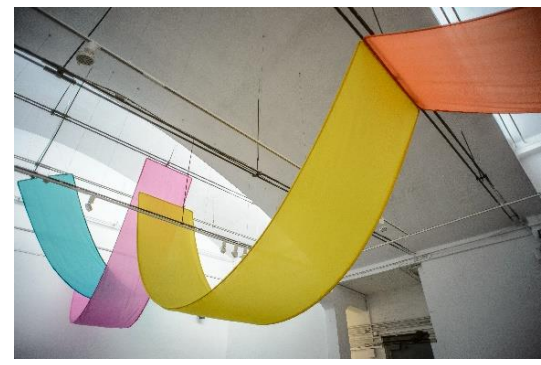

Punkty odniesienia (wersja odwrócona)

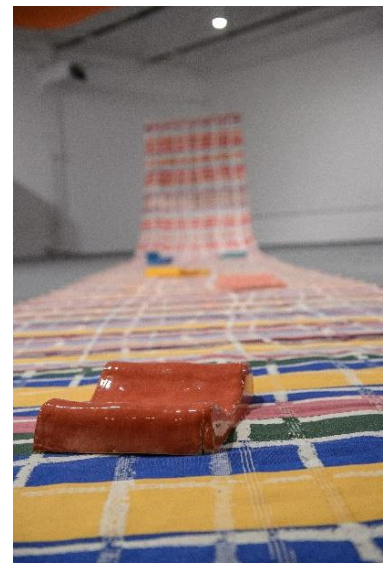

Wywinięte na druga strone - widok całej pracy i detal

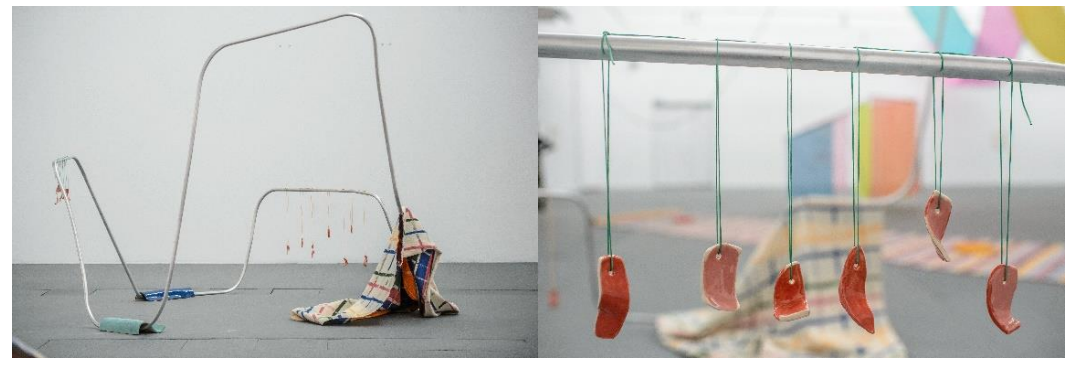


Magdalena Szubielska Wpływ zajęć edukacyjnych prowadzonych w przestrzeni galerii

Z serii Przemienny porzadek (A, B)

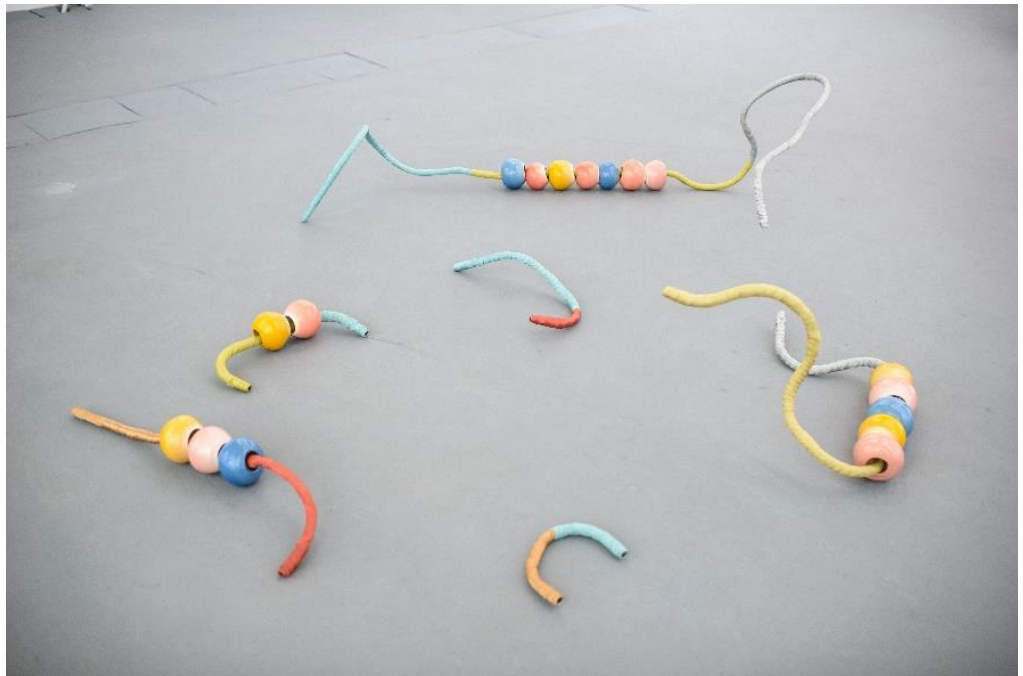


Aneks 3. Odpowiedzi na pytanie: „Jak myślisz, o czym chciała Ci opowiedzieć artystka, przygotowując tę wystawę?". W zapisach zachowano oryginalną dziecięcą pisownię.

Odpowiedzi uczniów z grupy kontrolnej (bez oprowadzania): „Że jest pomysłowa”; „Jak wygląda sztuka”; „Że tęcza jest bardzo ładna”; „Że to jest plac zabaw”; „Lubi tą sztukę”; ,Jaki ma talent”; ,Sztuka jest dziwna”; „Chciała pokazać kolory"; „Że ładnie maluje”; „Że to lubi”; „Atrakcje”; „Rozbudzić wyobraźnię”; „Że lubi sport”; „Że jest artystka z fantazją i wyobraźnią”; „Że chce powiedzieć, że świat jest kolorowy”; „O fantazji i wyobraźni, jakie barwy są kolorowe”; „Żeby pokazać komuś na urodziny”; „Jak bardzo lubi sztukę”; „Że ma coś przekazać”; „Chciała powiedzieć, że każdy przedmiot może przedstawiać kilka rzeczy”; „Chciała nam wskazać, że patrząc można zobaczyć różne rzeczy”; „O czym marzy”; „Bo chciała powitać wiosnę”; „Jeden autor dużo rzeczy”; „O tym, że życie jest kolorowe”; „Żeby dzieci lub dorośli byli podczas oglądania szczęśliwi”; „Że są szalone”; „Bo chciała zrobić najdziwniejszą pracę”; „Chciała zrobić najdziwniejszą pracę”; „Żeby zrobić wrażenie na innych”; „Chciała wykonać najdziwniejszą pracę”; „Chciała mi powiedzieć, że to bardzo ją zainspirowało, żeby dzieci ruszyły wyobraźnią"; „Chciała zrobić najdziwniejszą pracę”; „Że świat jest dziwny”; „Że nie trzeba robić prac z farbek i że prace mogą być z niepotrzebnych rzeczy”.

Odpowiedzi uczniów z grupy eksperymentalnej (z oprowadzaniem): „To jest to co sama zrobiłam”; „O kolorach”; „Co to znaczy kolor”; „Że kolory mogą zmienić rzeczy”; „Że jest atrakcyjna, wesoła”; „Że świat wygląda lepiej, gdy jest kolorowy”; „Że kolory nie są zwykłe, tylko wyjątkowe”; „O kolorach”; „O kolorach”; „Że świat bez kolorów jest nieciekawy”; „Że artysta nie musi zawsze być doskonały”; „Z czymś to nic nie wiemy, ale się dowiadujemy”; „Wyrazić swoje uczucia”; „Chciała zapytać, z czym nam się to kojarzy”; „Mówi o swoich humorach"; „Dobrą zabawę”; „Codzienność”; „Że nawet niestaranne prace mogą być ładne”; „Że te wszystkie rzeczy, nawet jeśli wyglądają byle jak, to nie znaczy, że są brzydkie”; „Żeby nauczyła mnie o sztuce”; „Że każdy człowiek robi błędy i nie zawsze to pobrzydza pracę”; „Że da się zrobić z metalu, gliny i materiału abstrakcje”; „Że Cię kocham”; „O kolorach”; „Że lubi kolory”; „O kolorach i o kształtach”; „Chciała pokazać świat sztuki”; „O kolorach”; „O kolorach”; „Że inspiruje się kolorami”; „Kocham kolory i lubię je kolorować”; „Kocham kolory”; „O miłości”; „Chciała pokazać kolory”; „Że życie jest radosne i kolorowe”; „O placu zabaw”; „Co najbardziej lubi”; „O kolorach 3D”; „Że uwielbia kolory”. 